\title{
Impact of Banker Customer Relationship on the Effective Ussage of the Techonology Enabled Services in Banks: An Empirical Evidence
}

\author{
*P.Satheesh babu \& **Dr.Y.Lokeswara Choudary \\ *Research Scholar, School of Management, SRM University, Kattankulathur, Chennai-603203. \\ **Asst.Professor \&Research supervisor, Department of Commerce, Govt.Arts College, Nandanam, Chennai- \\ 600035 .
}

\begin{abstract}
Entry of new banks resulted in a paradigm shift in the ways of banking in India. The growing competition and growing expectations led to increased awareness amongst banks on the role and importance of technology in banking. The arrival of foreign and private banks with their superior state-of-the-art technologybased services pushed Indian Banks also to follow suit by going in for the latest technologies so as to meet the threat of competition and retain their customer base. The success of technology enabled services offered by new age banks depends on the banker and customer relationship to a greater extent. In this view point the present study is taken up for research and to find out the role of banker and customer relationship on using the technology enabled services offered by the banks. Further, To analyze the association between banker and customer relationship and technology enabled services usage patterns in banks. This research has primarily been based on the primary data collected from the select respondent customers of the selected commercial banks in Chennai. The oral interview has also been conducted wherever necessary to add clarity to certain key issues. The sample size is found by using scientific method and fixed at 462 . The data required for the study is collected through sample survey using a structured questionnaire. The reliability of the questionnaire is tested through corn bach's alpha and found the reliability at 0.8653 .

The data analysis found that there is a significant relationship between the banker and customer relationship on using the technology enabled services offered by the banks in the sample area. In addition, the more the interaction with the banker, the level of awareness and the usage patterns are highly positive with regard to technology enabled services. Similarly, the association between banker and customer relationship and technology enabled services usage patterns in banks is found significant and there is an association between the annual income, number of times visiting a bank, type of account maintained, purpose of visiting a bank with the usage patterns of technology enabled services in banks. It indicates the good customer relationship management practices and its impact on the higher levels of the usage of technology enabled services for the benefit of the customers and to the improve the service quality in banks in the years to come.
\end{abstract}

Keywords: Service quality- banker customer relationship- type of account-CRM practices.

\section{Introduction}

Information technology refers to all forms of technology applied to processing, storing and transmitting information in electronic form. The physical equipments used for information processing include computers, communication equipments and networks, fax machines. Information is a processed data used for decision making during uncertainty. Information systems execute organized procedures that process and communicate information. Information technology extends far beyond the computational capabilities of computers. Entry of new banks resulted in a paradigm shift in the ways of banking in India. The growing competition and growing expectations led to increased awareness amongst banks on the role and importance of technology in banking. The arrival of foreign and private banks with their superior state-of-the-art technology-based services pushed Indian Banks also to follow suit by going in for the latest technologies so as to meet the threat of competition and retain their customer base. Indian banking industry, today is in the midst of an IT revolution. Combinations of regulatory and competitive reasons have led to increasing importance of total banking automation in the Indian Banking Industry. Information Technology has basically been used under two different avenues in Banking. One is Communication, Connectivity and other is Business Process Reengineering.

1.2: Objectives of the study

1. To find out the role of banker and customer relationship on using the technology enabled services offered by the banks.

2. To analyze the association between banker and customer relationship and technology enabled services usage patterns in banks. 


\section{3: Need for Study}

For a long time, Indian banks faced very little competition and operated in a protected economy. Now, well-computerized foreign banks are beginning to compete seriously with the nationalized banks. Banks which use IT mainly focus on three areas viz. Meeting a customer's service expectations, cutting down the costs, managing dynamic competitive environment. For this, the banks are venturing into new financial products and service options that would help them grow without losing existing customers. And any new financial product or service that a bank offers will be intrinsically related to technology. Automation is the basic thing that banks need to have in place.

\section{4: Research Methodology}

The present study has adopted both descriptive and analytical methodologies. The descriptive methodology has been focused on review in the literary evidences that are available through external and internal sources. As the study is based on the services and their satisfaction thereon. Measurement of satisfactory level is with respect to various service ingredients. Hence the analytical process has become inevitable, resulting in the adoption of analytical methodology. A questionnaire has been designed in four segments consisting of personal data, determinant of customer satisfaction, services provided by the bank. This research has primarily been based on the primary data collected from the select respondent customers of the selected commercial banks in Chennai. The oral interview has also been conducted wherever necessary to add clarity to certain key issues. The sample size is found by using scientific method and fixed at 462 . The data required for the study is collected through sample survey using a structured questionnaire. The reliability of the questionnaire is tested through corn bach's alpha and found the reliability at 0.8653 .

\section{5: Data Analysis and Interpretation}

In this section the analysis of the data is done by using the appropriate statistics through SPSS version 15. The first part of the study deals with descriptive statistics and the second part deals with inferential statistics. The major findings and the results of the analysis is discussed in the light of existing literature and presented in a brief manner.

Table 1: Distribution of sample on the basis of Experience

\begin{tabular}{|l|r|r|}
\hline \multicolumn{1}{|c|}{ Age Group in years } & Frequency & \multicolumn{1}{c|}{ Percentage } \\
\hline Below 20 & 59 & 12.8 \\
\hline $21-30$ & 198 & 42.9 \\
\hline $31-40$ & 150 & 32.5 \\
\hline Above 40 & 55 & 11.9 \\
\hline Total & 462 & 100.0 \\
\hline
\end{tabular}

It is observed from the table 1 that the majority of the customers in the sample survey using technological services offered by the banks are belongs to 21-30 years age, and it is followed by 31-40 years age group. It indicates the role of age in adopting and availing technological services offered by the banks. One predominant reason for such relation may be lack of time and relocation of employees from one place to other and long working hours not permitting them to go to bank physically. In addition, the work place may be equipped with the online facilities and could have founds easy to complete the financial payments and other transactions through online via technological services offered by banks. The easy and free from logistics and waiting time may motivate the customers to use such options.

Table 2: Distribution of Sample on the basis of Educational Stream

\begin{tabular}{|l|r|r|}
\hline Education Qualification & Frequency & \multicolumn{1}{|c|}{ Percentage } \\
\hline Upto SSLC & 91 & 19.7 \\
\hline HSC & 71 & 15.4 \\
\hline UG & 126 & 27.3 \\
\hline PG & 111 & 24.0 \\
\hline Professional & 63 & 13.6 \\
\hline Total & 462 & 100.0 \\
\hline
\end{tabular}

Source: Primary data/Questionnaire.

It is noted from the table 2, that the majority of the respondents in the sample using technical services offered by banks are under graduates and it is followed by post graduates. The simple reason could be the majority of them are technical back ground and working in IT firms having technical savvy. The way deal with things in both personal and professional life is through technology and online. Such outcomes are common and expected. It is the responsibility of the banks to propagate the need for going to electronic and technical services through 
explaining the advantages of it. In addition, technical services service quality needs to be improved to build the confidence and trust among the customers.

Table 3: Distribution of sample on the basis of occupation

\begin{tabular}{|l|r|r|}
\hline \multicolumn{1}{|c|}{ Occupation } & Frequency & Percentage \\
\hline Private Employee & 247 & 53.5 \\
\hline Government Employee & 87 & 18.8 \\
\hline Business & 59 & 12.8 \\
\hline Professional & 69 & 14.9 \\
\hline Total & 462 & 100.0 \\
\hline
\end{tabular}

Source: Primary data/Questionnaire.

It is found from the table 3, that the majority of the customers using technical services offered by banks are employees working in private organizations. It indicates that the private organizations are equipped with technical savvy, which can be allowed to use the technology services offered by banks. In addition, private employees won't get time to visit banks frequently during working time. It is also difficult for them to reach the banks located in distance places due to logistic issues and traffic. In such conditions private employees are used to go for technological services offered by banks.

Table 4: Distribution of sample on the basis of Annual income

\begin{tabular}{|l|r|r|}
\hline \multicolumn{1}{|c|}{ Annual Income in Lakhs } & Frequency & Percentage \\
\hline Below 1 & 170 & 36.8 \\
\hline $1-3$ & 177 & 38.3 \\
\hline $3-5$ & 71 & 15.4 \\
\hline Above 5 & 44 & 9.5 \\
\hline Total & 462 & 100.0 \\
\hline
\end{tabular}

It is noted from the table 4 , that the 38.3 percent of the sample respondents are belongs to the less than Rs. 3 lakhs per year. It indicates the usage of banking services in increasing in the recent past by the middle income group. It indicates a positive sign in the organized sector growth and development in the country. The reported incomes are more means the transparency of the financial deals. In addition, this group is the potential income group for technological services adoption in the years to come. The hidden threat is the cost of services to avail technology services needs to be kept under control to attract the lower income groups in to the orbit of technology services.

\section{6: Inferential Statistics}

Hypothesis-I: There is no relationship between the number of years holding a bank account and the dimensions of technology enabled services adoption in banks.

Table 1: showing Group Statistics along with ANOVA result

\begin{tabular}{|c|c|c|c|c|c|c|c|}
\hline & & \multicolumn{4}{|c|}{ No. of years holding Bank Account } & \multirow[b]{2}{*}{ F value } & \multirow[b]{2}{*}{ P value } \\
\hline & & Below 5 & $6-10$ & $11-15$ & Above 15 & & \\
\hline \multirow{2}{*}{$\begin{array}{l}\text { Awareness of } \\
\text { Services }\end{array}$} & Mean & 48.80 & 48.82 & 49.30 & 49.33 & 0.076 & 0.973 \\
\hline & SD & $(9.41)$ & $(9.47)$ & $(9.74)$ & $(10.35)$ & & \\
\hline \multirow{2}{*}{$\begin{array}{l}\text { Problems in } \\
\text { availing } \\
\text { services }\end{array}$} & Mean & 38.47 & 37.84 & 36.28 & 34.42 & 5.063 & 0.002 \\
\hline & SD & (6.19) & $(6.42)$ & (6.38) & $(8.60)$ & & \\
\hline \multirow{2}{*}{$\begin{array}{l}\text { Opinion about not } \\
\text { availing services }\end{array}$} & Mean & 37.49 & 35.77 & 35.07 & 30.72 & 9.183 & 0.000 \\
\hline & SD & $(6.50)$ & $(7.80)$ & $(6.95)$ & $(10.13)$ & & \\
\hline \multirow{2}{*}{$\begin{array}{l}\text { Influencing in } \\
\text { usage } \\
\text { of services }\end{array}$} & Mean & 40.05 & 40.34 & 38.00 & 38.17 & 4.134 & 0.007 \\
\hline & SD & $(5.10)$ & $(5.70)$ & $(5.92)$ & (6.19) & & \\
\hline \multirow{2}{*}{$\begin{array}{l}\text { Improve the } \\
\text { quality } \\
\text { of services }\end{array}$} & Mean & 60.60 & 60.31 & 58.70 & 57.19 & 2.301 & 0.076 \\
\hline & SD & (7.83) & $(8.25)$ & (9.31) & (10.01) & & \\
\hline
\end{tabular}

Since $p$ value is less than 0.05 , the null hypothesis is accepted at $5 \%$ level of significance and explaining the no relationship between the tenure of bank account maintained with the level of awareness of technology enabled services among the customers in the sample area, where as there is a relationship between the tenure of account maintained with bank and the problems in availing the technology enabled services, reasons for not availing the technology enabled services, factors influencing usage of technology enabled services and suggestions to improve the quality of services in banks and indicates at highly significant relationship with the $p$ value of less 
than 0.001 and 0.05 respectively. Based on the mean value, the higher the account holding period leads to improve the usage patterns of selected technology enabled servies but not the overall level of awareness.

Hypothesis-II: There is no relationship between the number of times visiting a bank and the dimensions of technology enabled services adoption in banks.

Table 2: Group Statistics along with ANOVA Result

\begin{tabular}{|c|c|c|c|c|c|c|}
\hline & & \multicolumn{3}{|c|}{$\begin{array}{l}\text { No. of times visiting } \\
\text { bank per month }\end{array}$} & \multirow[t]{2}{*}{$F$ value } & \multirow[t]{2}{*}{$P$ value } \\
\hline & & Below 3 & $3-5$ & Above 5 & & \\
\hline \multirow{2}{*}{$\begin{array}{l}\text { Awareness of } \\
\text { Services }\end{array}$} & Mean & 49.13 & 49.32 & 47.61 & 0.971 & 0.379 \\
\hline & SD & $(9.84)$ & $(9.91)$ & $(7.81)$ & & \\
\hline \multirow{2}{*}{$\begin{array}{l}\text { Problems in availing } \\
\text { services }\end{array}$} & Mean & 37.44 & 38.54 & 36.27 & 3.354 & 0.036 \\
\hline & SD & $(6.74)$ & $(6.19)$ & $(6.77)$ & & \\
\hline \multirow{2}{*}{$\begin{array}{l}\text { Opinion about not } \\
\text { availing services }\end{array}$} & Mean & 35.94 & 36.79 & 34.59 & 2.310 & 0.100 \\
\hline & SD & $(7.59)$ & $(7.72)$ & $(7.09)$ & & \\
\hline \multirow{2}{*}{$\begin{array}{l}\text { Influencing in usage } \\
\text { of services }\end{array}$} & Mean & 40.27 & 40.65 & 36.33 & 20.077 & 0.000 \\
\hline & SD & $(4.94)$ & $(5.79)$ & $(5.68)$ & & \\
\hline \multirow{2}{*}{$\begin{array}{l}\text { Improve the quality } \\
\text { of services }\end{array}$} & Mean & 60.88 & 60.81 & 55.82 & 12.712 & 0.000 \\
\hline & SD & (8.47) & $(7.72)$ & $(8.50)$ & & \\
\hline
\end{tabular}

Since $\mathrm{p}$ value is less than 0.001 , the null hypothesis, There is no relationship between the number of times visiting a bank and the dimensions of factors influencing the usage of technology enabled services, suggestions to improve the technology enabled services adoption in banks is rejected at $1 \%$ level of significance. On the other hand, the level of awareness, problems in availing the technology enabled services and reasons for not using technology enabled services in banks is accepted at 5\% level of significance, indicates there is no relationship between the number of times visiting to bank and the usage awareness and problems among the customers.

Hypothesis-III: There is no relationship between the type of bank account maintained and the dimensions of technology enabled services adoption in banks.

Table 3: Group Statistics along with ANOVA Result

\begin{tabular}{|c|c|c|c|c|c|c|c|}
\hline & & \multicolumn{4}{|c|}{ Type of bank account maintained } & \multirow[b]{2}{*}{$\mathrm{F}$ value } & \multirow[b]{2}{*}{$P$ value } \\
\hline & & $\begin{array}{l}\text { Public } \\
\text { Sector } \\
\text { Bank } \\
\end{array}$ & $\begin{array}{l}\text { Private } \\
\text { Sector } \\
\text { Bank }\end{array}$ & $\begin{array}{l}\text { Foreign } \\
\text { Bank }\end{array}$ & $\begin{array}{l}\text { Co-op } \\
\text { Bank }\end{array}$ & & \\
\hline \multirow{2}{*}{$\begin{array}{l}\text { Awareness of } \\
\text { Services }\end{array}$} & Mean & 49.22 & 48.90 & 46.44 & 48.40 & 0.669 & 0.571 \\
\hline & SD & $(9.22)$ & $(9.91)$ & $(10.25)$ & $(9.60)$ & & \\
\hline \multirow{2}{*}{$\begin{array}{l}\text { Problems in } \\
\text { availing services }\end{array}$} & Mean & 38.23 & 37.23 & 37.20 & 33.10 & 4.156 & 0.006 \\
\hline & SD & $(6.07)$ & $(6.78)$ & $(8.04)$ & $(7.99)$ & & \\
\hline \multirow{2}{*}{$\begin{array}{l}\text { Opinion about } \\
\text { not availing services }\end{array}$} & Mean & 37.18 & 34.67 & 34.48 & 33.45 & 4.945 & 0.002 \\
\hline & SD & $(7.02)$ & $(7.97)$ & $(7.54)$ & $(8.78)$ & & \\
\hline \multirow{2}{*}{$\begin{array}{l}\text { Influencing in } \\
\text { usage of services }\end{array}$} & Mean & 40.44 & 39.02 & 37.60 & 38.25 & 3.964 & 0.008 \\
\hline & $\mathrm{SD}$ & $(5.19)$ & $(6.06)$ & $(4.95)$ & $(6.02)$ & & \\
\hline \multirow{2}{*}{$\begin{array}{l}\text { Improve the } \\
\text { quality of services }\end{array}$} & Mean & 60.70 & 59.75 & 56.44 & 56.30 & 3.447 & 0.017 \\
\hline & SD & $(8.04)$ & (8.64) & $(9.13)$ & $(9.28)$ & & \\
\hline
\end{tabular}

There is a relationship between the type of bank account maintained and the dimensions of problems faced in using the technology enabled services, reasons for not using, and factors influencing the usage of technology enabled services adoption in banks and it is statistically significant at $1 \%$ level with the recorded $p$ value of less than 0.001. On the other hand, it is observed that there is no relationship between the type of bank account maintained and the dimensions of level of awareness, suggestions to improve the usage of technology enabled services adoption in banks with the recorded $p$ value of less than 0.05 at $5 \%$ level of significance.

Analysis of data using chi-square test:

Null Hypothesis (Ho): There is no association between the number of years holding an account and the level of awareness on technology enables services among the customers. 
Table 4: Cross Table along with Chi-square Result

\begin{tabular}{|c|c|c|c|c|c|c|}
\hline \multirow{2}{*}{\multicolumn{2}{|c|}{ No. of years holding Bank Account }} & \multicolumn{3}{|c|}{ Level of Awareness of Services } & \multirow{2}{*}{$\begin{array}{l}\text { Chi-Square } \\
\text { Value }\end{array}$} & \multirow[t]{2}{*}{ P-Value } \\
\hline & & Low & Average & High & & \\
\hline \multirow[t]{3}{*}{ Below 5} & Count & 56 & 85 & 51 & \multirow{15}{*}{11.199} & \multirow{15}{*}{.082} \\
\hline & $\begin{array}{l}\text { \% within No. of years holding Bank } \\
\text { Account }\end{array}$ & $29.2 \%$ & $44.3 \%$ & $26.6 \%$ & & \\
\hline & $\begin{array}{l}\text { \% within Level of Awareness of } \\
\text { Services }\end{array}$ & $42.7 \%$ & $41.9 \%$ & $39.8 \%$ & & \\
\hline \multirow[t]{3}{*}{$6-10$} & Count & 41 & 82 & 40 & & \\
\hline & $\begin{array}{l}\text { \% within No. of years holding Bank } \\
\text { Account }\end{array}$ & $25.2 \%$ & $50.3 \%$ & $24.5 \%$ & & \\
\hline & $\begin{array}{l}\% \text { within Level of Awareness of } \\
\text { Services }\end{array}$ & $31.3 \%$ & $40.4 \%$ & $31.3 \%$ & & \\
\hline \multirow[t]{3}{*}{$11-15$} & Count & 19 & 28 & 24 & & \\
\hline & $\begin{array}{l}\text { \% within No. of years holding Bank } \\
\text { Account }\end{array}$ & $26.8 \%$ & $39.4 \%$ & $33.8 \%$ & & \\
\hline & $\begin{array}{l}\% \text { within Level of Awareness of } \\
\text { Services }\end{array}$ & $14.5 \%$ & $13.8 \%$ & $18.8 \%$ & & \\
\hline \multirow[t]{3}{*}{ Above 15} & Count & 15 & 8 & 13 & & \\
\hline & $\begin{array}{l}\text { \% within No. of years holding Bank } \\
\text { Account }\end{array}$ & $41.7 \%$ & $22.2 \%$ & $36.1 \%$ & & \\
\hline & $\begin{array}{l}\% \text { within Level of Awareness of } \\
\text { Services }\end{array}$ & $11.5 \%$ & $3.9 \%$ & $10.2 \%$ & & \\
\hline \multirow[t]{3}{*}{ Total } & Count & 131 & 203 & 128 & & \\
\hline & $\begin{array}{l}\% \text { within No. of years holding Bank } \\
\text { Account }\end{array}$ & $28.4 \%$ & $43.9 \%$ & $27.7 \%$ & & \\
\hline & $\begin{array}{l}\% \text { within Level of Awareness of } \\
\text { Services }\end{array}$ & $100.0 \%$ & $100.0 \%$ & $100.0 \%$ & & \\
\hline
\end{tabular}

Since $\mathrm{p}$ value is less than 0.05 , the null hypothesis, There is no association between the number of years holding an account and the level of awareness on technology enables services among the customers is accepted at $5 \%$ level of significance. It indicates the moderate level of association between the number of years holding an account and the level of awareness on technology enables services among the customers.

Null Hypothesis (Ho): There is no association between Locality and the level of awareness on technology enables services among the customers.

Table 5 :Cross Table along with Chi-square Result

\begin{tabular}{|c|c|c|c|c|c|c|}
\hline \multirow[b]{2}{*}{ Locality } & & \multicolumn{3}{|c|}{ Level of Awareness of Services } & \multirow{2}{*}{$\begin{array}{l}\text { Chi-Square } \\
\text { Value }\end{array}$} & \multirow{2}{*}{ P-Value } \\
\hline & & Low & Average & High & & \\
\hline \multirow[t]{3}{*}{ Urban } & Count & 91 & 153 & 100 & \multirow{9}{*}{2.711} & \multirow{9}{*}{.258} \\
\hline & \% within Locality & $26.5 \%$ & $44.5 \%$ & $29.1 \%$ & & \\
\hline & $\begin{array}{l}\% \text { within Level of Awareness of } \\
\text { Services }\end{array}$ & $69.5 \%$ & $75.4 \%$ & $78.1 \%$ & & \\
\hline \multirow[t]{3}{*}{ Semi urban } & Count & 40 & 50 & 28 & & \\
\hline & $\%$ within Locality & $33.9 \%$ & $42.4 \%$ & $23.7 \%$ & & \\
\hline & $\begin{array}{l}\% \text { within Level of Awareness of } \\
\text { Services }\end{array}$ & $30.5 \%$ & $24.6 \%$ & $21.9 \%$ & & \\
\hline \multirow[t]{3}{*}{ Total } & Count & 131 & 203 & 128 & & \\
\hline & \% within Locality & $28.4 \%$ & $43.9 \%$ & $27.7 \%$ & & \\
\hline & $\begin{array}{l}\text { \% within Level of Awareness of } \\
\text { Services }\end{array}$ & $100.0 \%$ & $100.0 \%$ & $100.0 \%$ & & \\
\hline
\end{tabular}

Since $\mathrm{p}$ value is greater than 0.05 , the null hypothesis, There is no association between Locality and the level of awareness on technology enables services among the customers is accepted at $5 \%$ level of significance. It is conclude that there is no association between Locality and the level of awareness on technology enables services among the customers in the sample area.

Null Hypothesis (Ho): There is no association between the number of times visiting a bank and the level of awareness on technology enables services among the customers. 
Table 6: Cross Table along with Chi-square Result

\begin{tabular}{|c|c|c|c|c|c|c|}
\hline \multirow{2}{*}{\multicolumn{2}{|c|}{ No. of times visiting bank per month }} & \multicolumn{3}{|c|}{ Level of Awareness of Services } & \multirow{2}{*}{$\begin{array}{l}\text { Chi- } \\
\text { Square } \\
\text { Value }\end{array}$} & \multirow[b]{2}{*}{ P-Value } \\
\hline & & Low & Average & High & & \\
\hline \multirow[t]{3}{*}{ Below 3} & Count & 66 & 87 & 71 & \multirow{12}{*}{8.454} & \multirow{12}{*}{.076} \\
\hline & $\begin{array}{l}\% \text { within No. of times visiting bank } \\
\text { per month }\end{array}$ & $29.5 \%$ & $38.8 \%$ & $31.7 \%$ & & \\
\hline & $\begin{array}{l}\% \text { within Level of Awareness of } \\
\text { Services }\end{array}$ & $50.4 \%$ & $42.9 \%$ & $55.5 \%$ & & \\
\hline \multirow[t]{3}{*}{$3-5$} & Count & 40 & 72 & 43 & & \\
\hline & $\begin{array}{l}\% \text { within No. of times visiting bank } \\
\text { per month }\end{array}$ & $25.8 \%$ & $46.5 \%$ & $27.7 \%$ & & \\
\hline & $\begin{array}{l}\% \text { within Level of Awareness of } \\
\text { Services }\end{array}$ & $30.5 \%$ & $35.5 \%$ & $33.6 \%$ & & \\
\hline \multirow[t]{3}{*}{ Above 5} & Count & 25 & 44 & 14 & & \\
\hline & $\begin{array}{l}\% \text { within No. of times visiting bank } \\
\text { per month }\end{array}$ & $30.1 \%$ & $53.0 \%$ & $16.9 \%$ & & \\
\hline & $\begin{array}{l}\% \text { within Level of Awareness of } \\
\text { Services }\end{array}$ & $19.1 \%$ & $21.7 \%$ & $10.9 \%$ & & \\
\hline \multirow[t]{3}{*}{ Total } & Count & 131 & 203 & 128 & & \\
\hline & $\begin{array}{l}\% \text { within No. of times visiting bank } \\
\text { per month }\end{array}$ & $28.4 \%$ & $43.9 \%$ & $27.7 \%$ & & \\
\hline & $\begin{array}{l}\% \text { within Level of Awareness of } \\
\text { Services }\end{array}$ & $100.0 \%$ & $100.0 \%$ & $100.0 \%$ & & \\
\hline
\end{tabular}

Since $\mathrm{p}$ value is greater than 0.05 , the null hypothesis, There is no association between the number of times visiting a bank and the level of awareness on technology enables services among the customers is accepted at $5 \%$ level of significance. Hence, There is no association between the number of times visiting a bank and the level of awareness on technology enables services among the customers.

Null Hypothesis (Ho): There is no association between the purpose of visiting a bank and the level of awareness on technology enables services among the customers.

Table 7: Cross Table along with Chi-square Result

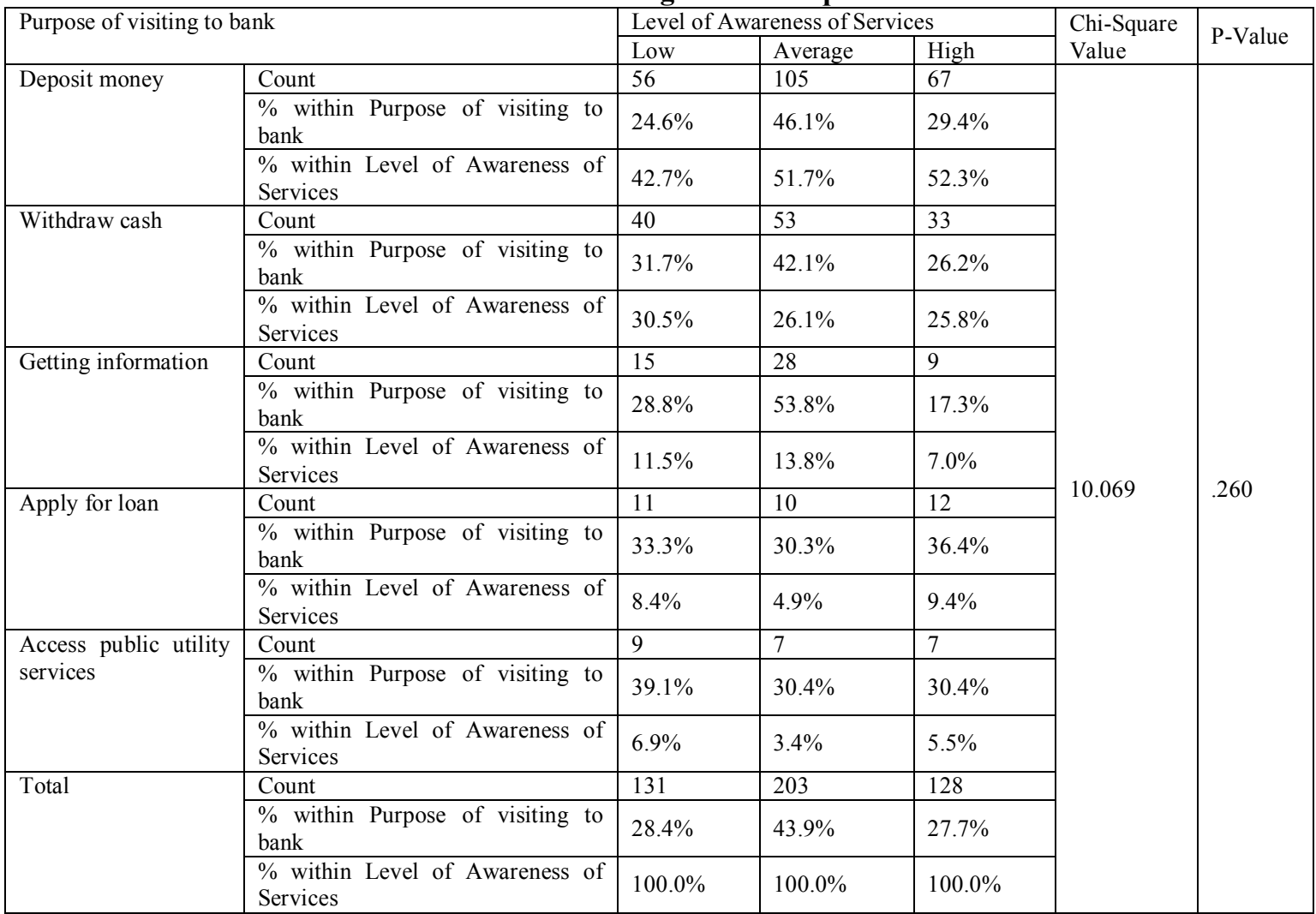

Since $\mathbf{p}$ value is greater than $\mathbf{0 . 0 5}$, the null hypothesis, There is no association between the purpose of visiting a bank and the level of awareness on technology enables services among the customers is accepted at 5\% level 
of significance. Hence, it is inferred that, There is no association between the purpose of visiting a bank and the level of awareness on technology enables services among the customers.

Null Hypothesis (Ho): There is no association between the type of account maintained and the level of awareness on technology enables services among the customers.

Table 8: Cross Table along with Chi-square Result

\begin{tabular}{|c|c|c|c|c|c|c|}
\hline \multirow{2}{*}{\multicolumn{2}{|c|}{ Type of bank account maintained }} & \multicolumn{3}{|c|}{ Level of Awareness of Services } & \multirow{2}{*}{$\begin{array}{l}\text { Chi-Square } \\
\text { Value }\end{array}$} & \multirow{2}{*}{ P-Value } \\
\hline & & Low & Average & High & & \\
\hline \multirow[t]{3}{*}{ Public Sector Bank } & Count & 66 & 125 & 63 & \multirow{15}{*}{10.113} & \multirow{15}{*}{.120} \\
\hline & $\begin{array}{l}\% \text { within Type of bank account } \\
\text { maintained }\end{array}$ & $26.0 \%$ & $49.2 \%$ & $24.8 \%$ & & \\
\hline & $\begin{array}{l}\% \text { within Level of Awareness of } \\
\text { Services }\end{array}$ & $50.4 \%$ & $61.6 \%$ & $49.2 \%$ & & \\
\hline \multirow[t]{3}{*}{ Private Sector Bank } & Count & 50 & 59 & 54 & & \\
\hline & $\begin{array}{l}\% \text { within Type of bank account } \\
\text { maintained }\end{array}$ & $30.7 \%$ & $36.2 \%$ & $33.1 \%$ & & \\
\hline & $\begin{array}{l}\% \text { within Level of Awareness of } \\
\text { Services }\end{array}$ & $38.2 \%$ & $29.1 \%$ & $42.2 \%$ & & \\
\hline \multirow[t]{3}{*}{ Foreign Bank } & Count & 10 & 11 & 4 & & \\
\hline & $\begin{array}{l}\% \text { within Type of bank account } \\
\text { maintained }\end{array}$ & $40.0 \%$ & $44.0 \%$ & $16.0 \%$ & & \\
\hline & $\begin{array}{l}\% \text { within Level of Awareness of } \\
\text { Services }\end{array}$ & $7.6 \%$ & $5.4 \%$ & $3.1 \%$ & & \\
\hline \multirow[t]{3}{*}{ Co-operative Bank } & Count & 5 & 8 & 7 & & \\
\hline & $\begin{array}{l}\% \text { within Type of bank account } \\
\text { maintained }\end{array}$ & $25.0 \%$ & $40.0 \%$ & $35.0 \%$ & & \\
\hline & $\begin{array}{l}\% \text { within Level of Awareness of } \\
\text { Services }\end{array}$ & $3.8 \%$ & $3.9 \%$ & $5.5 \%$ & & \\
\hline \multirow[t]{3}{*}{ Total } & Count & 131 & 203 & 128 & & \\
\hline & $\begin{array}{l}\% \text { within Type of bank account } \\
\text { maintained }\end{array}$ & $28.4 \%$ & $43.9 \%$ & $27.7 \%$ & & \\
\hline & $\begin{array}{l}\% \text { within Level of Awareness of } \\
\text { Services }\end{array}$ & $100.0 \%$ & $100.0 \%$ & $100.0 \%$ & & \\
\hline
\end{tabular}

Since $\mathrm{p}$ value is greater than 0.05 , the null hypothesis, There is no association between the type of account maintained and the level of awareness on technology enables services among the customers is accepted at $5 \%$ level of significance. Hence, it is inferred that, there is no association between the type of account maintained and the level of awareness on technology enables services among the customers.

\section{Summary and Conclusion:}

Based on the analysis and discussion, it is observed that there is a relationship between the usage of technology enabled services and the relationship between the banker and customer. It indicates that the banker customer relationship is needed for the enhancement and effective usage of the banking and advanced technology enabled services adoption and implementation in the banks. The association between the selected demographics and the awareness, problems in aviling, reasons for not using and factors influencing technology enabled services in banks is not statistically significant at $5 \%$ level among the sample respondents. It indicates the poor level of impact of demographics on the usage patterns of technology enabled services in banks. The effective implementation requires wide publicity, and customer friendly simple systems in place.

\section{References:}

[1]. Lovelock, Christopher (2001), Services marketing; people, Technology, strategy, $4^{\text {th }}$ edition, prentice Hall.

[2]. Lev, B, (2001), Intangible management, measurement and reporting Washington DC;Brookings Institute press.

[3]. Carl D. McDaniel (2005). The Future of Business: The Essentials Mason, Ohio: South-Western. ISBN 0324320280.

[4]. John, Joby (2003). Fundamentals of Customer-Focused Management: Competing Through Service. Westport, Conn.: Praeger. ISBN 9781567205640 .

[5]. Kessler, Sheila (2003)., Customer satisfaction toolkit for ISO 9001:2000. Milwaukee,Wis.: ASQ Quality Press. ISBN 0873895592.

[6]. Johnson, Michael D.; Anders Gustafssonb, Tor Wallin Andreassenc, Line Lervikc andJaesung Cha (2001). "The evolution and future of national customer satisfaction index models". Journal of Economic Psychology 22(2): 217-245.ISSN 0167-4870.

[7]. Bluestein, Abram; Michael Moriarty; Ronald J Sanderson (2003).The Customer Satisfaction Audit. Axminster: Cambridge Strategy Publications.ISBN 9781902433981..

[8]. Rexha N, kingshott RPJ and AW ASS (2003) “The impact of Relational plan onAdoption of electronic Banking” Journal of service marketing, Vol.17. 